\title{
Implementasi Fuzzy Tsukamoto dalam Prediksi Produksi Madu Trigona
}

\author{
I Made Arya Budhi Saputra ${ }^{1}$, Ni Wayan Risa Rahayu Setiawati ${ }^{2}$, Ida Bagus Nyoman Pascima ${ }^{3}, \mathrm{Ni}^{\mathbf{2}}$ \\ Nyoman Utami Januhari ${ }^{4}$ \\ ${ }^{1,4}$ Fakultas Informatika dan Komputer, ${ }^{3}$ Fakultas Teknik dan Kejuruan, ${ }^{2}$ Fakultas Bisnis dan Vokasi \\ ${ }^{1,2,4}$ Institut Teknologi dan Bisnis STIKOM Bali, ${ }^{3}$ Universitas Pendidikan Ganesha \\ Denpasar, Indonesia \\ e-mail: ${ }^{1}$ aryabudhi@stikom-bali.ac.id, ${ }^{2}$ rrisa329@gmail.com, ${ }^{3}$ gus.pascima@undiksha.ac.id, \\ 4amik@stikom-bali.ac.id
}

Diajukan: 17 Mei 2021; Direvisi: 15 Juni 2021; Diterima: 30 Juni 2021

\begin{abstract}
Abstrak
Madu trigona merupakan madu yang penuh khasiat. Selain penuh khasiat, madu trigona pada saat panen tidak memerlukan kemampuan atau skill khusus serta mudah dalam proses pemeliharaan. Di daerah Kerandangan (Lombok Barat) terdapat sebuah kelompok tani yang membudidayakan madu ini. Kelompok tani ini memiliki beberapa titik lokasi untuk peternakan lebah madu. Jumlah permintaan menyebabkan produksi madu mengalami fluktuatif yang berimbas pada penghasilan dari kelompok tani ini. Selain itu fluktuatifnya jumlah permintaan menyebabkan tidak efisiennya penggunaan tenaga kerja dalam proses produksi. Kelompok tani ini sering kali salah dalam melakukan prediksi dalam jumlah produksi dari madu yang dihasilkan. Fuzzy Tsukamoto merupakan metode yang digunakan pada penelitian ini. Salah satu kelebihan dari metode ini memiliki kemampuan berupa intuisi dengan informasi yang bersifat kualitatif. Nilai produksi minimal madu trigona pada kelompok tani ini sebanyak 3 botol dan nilai maksimal produksi sebanyak 10 botol. Terdapat 4 inferensi rule yang digunakan pada penelitian ini. Hasil dari penggunaan metode menghasilkan nilai akurasi prediksi sebesar $92.40 \%$.
\end{abstract}

Kata kunci: Madu, Trigona, Prediksi, Tsukamoto.

Abstract

Trigona honey is honey that is full of benefits. Apart from being full of benefits, this honey is quite easy to maintain and does not require special expertise in the harvest process. In the Kerandangan area (West Lombok) there is a group of farmers who cultivate this honey. This farmer group has several location points for honey bee farming. The amount of demand causes honey production to fluctuate which impacts on the income of this farmer group. Besides that, the fluctuation in the amount of demand causes inefficient use of labor in the production process. This farmer group is often wrong in predicting the amount of production from the honey produced. Fuzzy Tsukamoto is the method used in this study. The advantage of this method is that it is intuitive and can provide responses based on qualitative information. The minimum production value of trigone honey in this farmer group is 3 bottles and the maximum production value is 10 bottles. There are 4 inference rules used in this study. The results from using the method resulted in a predictive accuracy value of $92.40 \%$.

Keywords: Honey, Trigona, Prediction, Tsukamoto.

\section{Pendahuluan}

Madu merupakan cairan alami yang dihasilkan oleh lebah madu dari sari bunga (floral nektar) atau bagian lain dari tanaman (ekstra floral nektar). Madu trigona merupakan madu yang cukup banyak dikonsumsi oleh masyarakat pada saat ini karena khasiatnya tersebut. Madu ini cukup mudah dalam pemeliharaan dan tidak membutuhkan keahlian khusus dalam proses panen, hasil madu yang tidak tergantung pada musim pembungaan [1].

Ada beberapa jenis lebah madu yang terdapat di Indonesia antara lain: (a) Apis Indica yaitu lebah lokal yang disebut Nyiruan (Sunda) atau Tawon (Jawa); (b) Apis Dorsata yaitu lebah hutan yang biasanya disebut Odeng (Sunda) atau Tawon Gung (Jawa); (c) Trigona SP yang sering disebut Gala-Gala, Teuwel (Sunda), atau Klanceng (Jawa) . 
Sedangkan beberapa jenis madu yang terdapat di Indonesia antara lain: (a) Madu Kopi yaitu madu yang dihasilkan dari nectar bunga kopi yang memiliki aroma khas yaitu manis dan sekilas tercium aroma kopinya; (b) Madu Kaliandra yaitu madu yang dihasilkan dari nectar bunga Kaliandra yang biasanya dikonsumsi untuk alasan kesehatan seperti susah buang air besar dan untuk hipertensi; (c) Madu Tawon Gung merupakan salah satu madu termahal karena madunya yang jarang dan sulit ditemukan. Hal ini karena habitat dari tawon gung yang berada di gunung dan cukup sulit untuk diternakkan. Menjadi salah satu madu termahal karena langka dan sulit didapatkan; (d) Madu Hutan merupakan madu yang dihasilkan oleh lebah liar pengisap nectar bunga di hutan. Madu hutan sendiri terdapat di beberapa wilayah di Indonesia seperti Sumatra, NTT, dan yang cukup terkenal Madu Hutan Sumbawa. Madu yang dihasilkan pun berbeda-beda dari segi warna maupun rasa, hal tersebut dikarenakan jenis bunga yang terdapat di hutan tiap daerah berbeda-beda; (e) Madu Kelengkeng, seperti namanya madu ini dihasilkan dari lebah yang menghisap dari nectar bunga dari pohon kelengkeng. Rasa madu yang manis dan gurih layaknya buah kelengkeng menjadi ciri khas madu ini [2].

Madu Klanceng merupakan madu yang dihasilkan dari lebah yang menghisap nectar dari beragam jenis bunga. Rasa madu yang agak pahit menjadikan madu ini baik dikonsumsi oleh penderita diabetes sebagai pengganti insulin dalam tubuh. Madu ini juga memiliki khasiat menurunkan kadar gula berlebih dan menyeimbangkan metabolisme tubuh. Madu ini juga dikenal dengan nama Madu Trigona, sesuai dengan jenis lebah penghasil madu ini yaitu Trigona SP [1].

Lebah Trigona (Trigona SP) merupakan jenis lebah madu tak bersengat (stingless honey bees) yang dapat ditemukan di wilayah yang beriklim tropis dan beberapa daerah beriklim subtropis. Jenis Trigona yang ada di bumi diperkirakan berjumlah ratusan jenis, namun sulit dibedakan karena kedekatan kekerabatan mereka [3].

Lebah Trigona SP diketahui dapat menghasilkan madu yang mempunyai kandungan vitamin C yang berfungsi sebagai antibiotik, antitoksin, antioksidan, serta untuk meningkatkan sistem imun atau kekebalan tubuh. Madu Trigona dikenal sangat kaya propolis. Kandungan propolis yang tinggi inilah salah satu faktor penyebab kenapa madu trigona begitu kaya manfaat untuk kesehatan dan terapi penyakit [2].

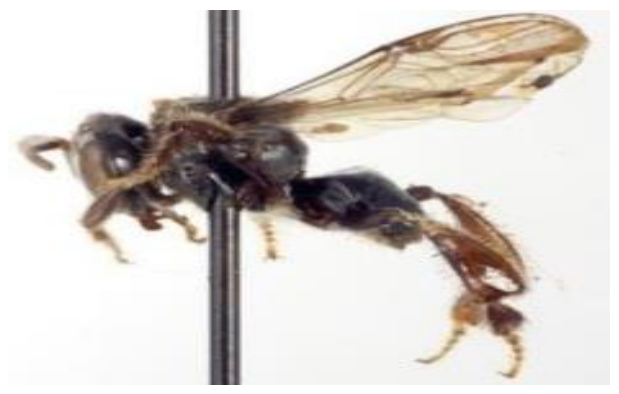

Gambar 1. Lebah Trigona.

Di daerah Kerandangan (Lombok Barat) terdapat sebuah kelompok tani yang membudidayakan madu ini. Kelompok tani ini memiliki beberapa titik lokasi untuk peternakan lebah madu. Jumlah permintaan menyebabkan produksi madu mengalami fluktuatif yang berimbas pada penghasilan dari kelompok tani ini. Selain itu fluktuatifnya jumlah permintaan menyebabkan tidak efisiennya penggunaan tenaga kerja dalam proses produksi. Kelompok tani ini sering kali salah dalam melakukan prediksi dalam jumlah produksi dari madu yang dihasilkan.

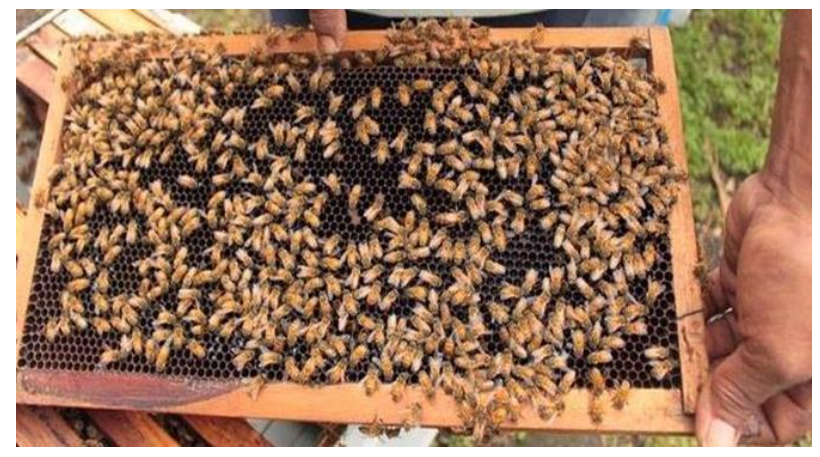

Gambar 2. Sarang Lebah Trigona. 
Penggunaan sistem informasi untuk memprediksi jumlah produksi hasil madu berdasarkan jumlah permintaan dapat membantu penentuan jumlah produksi yang tepat bagi kelompok tani. Sistem Informasi Prediksi dapat membantu permasalahan yang ditemui oleh kelompok tani, khususnya dalam memprediksi jumlah madu yang dihasilkan pada proses produksi.

\section{Metode Penelitian}

Pada penelitian ini menggunakan metode kepustakaan di mana penulis menggunakan sejumlah referensi dari buku dan penelitian lainya yang berkaitan dengan madu trigona, prediksi dan fuzzy tsukamoto. Penelitian ini bersifat deskriptif, di mana hasil penelitian ini disampaikan dalam bentuk deskripsi yang bersifat kualitatif maupun kuantitatif.

Penelitian ini juga menggunakan metode analisis data dan observasi di mana peneliti terjun langsung ke lokasi untuk mengetahui tentang permintaan jumlah madu dan produksi madu. Penelitian ini bersifat eksploratif, di mana penelitian ini dilakukan dengan cara menggali informasi untuk penggunaan sistem informasi dan metode Fuzzy Tsukamoto sebagai metode dalam memprediksi hasil produksi madu trigona berdasarkan jumlah permintaan

Metode Fuzzy Tsukamoto merupakan metode yang akan digunakan dalam sistem informasi prediksi tersebut. Kelebihan dari metode ini yaitu bersifat intuitif dan dapat memberikan tanggapan berdasarkan informasi yang bersifat kualitatif [4].

Pada metode ini, memiliki rule yang berbentuk if-then harus digambarkan dengan suatu himpunan fuzzy dengan fungsi keanggotaan yang tidak berubah sebagai hasilnya (proses fuzzifikasi) [5]. Keluaran hasil inferensi dari tiap rule diberikan secara tegas ( crisp) berdasarkan $\alpha$-predikat. Hasil akhirnya diperoleh dengan menggunakan defuzzifikasi rata-rata terbobot [6][7].

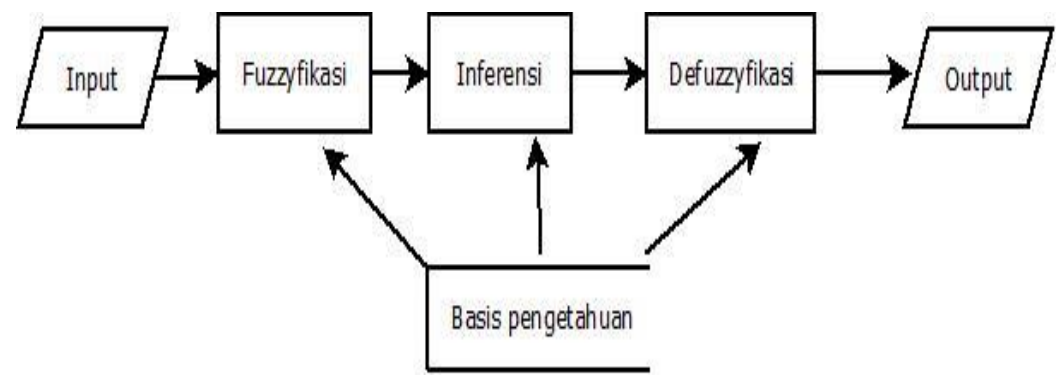

Gambar 3. Tahapan pada metode Fuzzy.

\section{Fuzzifikasi}

Fuzzifikasi adalah satu tahapan mengubah nilai input dari nilai tegas (crisp) menjadi himpunan fuzzy guna menentukan derajat keanggotaan pada himpunan tersebut.[8]

2. Pembentukan Rules If-Then

Tahapan pembentukan aturan (rule) yang tersimpan dalam basis keanggotaan fuzzy.

\section{Mesin Inferensi}

Tahapan mengubah nilai input fuzzy menjadi output fuzzy dengan proses fuzzifikasi tiap aturan (rule) yang telah ditetapkan. Menggunakan fungsi implikasi MIN untuk mendapatkan nilai alpha-predikat tiap-tiap rule. Kemudian masing-masing nilai alpha-predikat digunakan untuk menghitung output masing-masing rule (nilai z) [9].

\section{Defuzzifikasi}

Mengubah output fuzzy yang diperoleh dari mesin inferensi menjadi nilai crisp [10]. Metode rata-rata Weight Average digunakan untuk memperoleh hasil akhir. Menjelaskan kronologis penelitian, termasuk desain penelitian, prosedur penelitian (dalam bentuk algoritma, pseudocode, atau lainnya), bagaimana menguji dan mengumpulkan data [1],[3]. Deskripsi alur penelitian harus didukung oleh referensi sehingga penjelasan yang ditulis dapat diterima secara ilmiah.

\section{Hasil dan Pembahasan}

\subsection{Deskripsi Data}

Dari observasi yang dilakukan selama 5 bulan mulai dari bulan Juni tahun 2020 hingga Oktober 2020 maka diperoleh hasil sejumlah data seperti yang tercantum pada Tabel 1 di bawah ini: 
Tabel 1. Data observasi.

\begin{tabular}{|c|c|c|c|c|}
\hline $\begin{array}{c}\text { Waktu Pelaksanaan } \\
\text { (minggu ke-) }\end{array}$ & Bulan & $\begin{array}{c}\text { Persediaan } \\
\text { (botol) }\end{array}$ & $\begin{array}{c}\text { Permintaan } \\
\text { (botol) }\end{array}$ & $\begin{array}{c}\begin{array}{c}\text { Produksi } \\
\text { (botol) }\end{array} \\
\end{array}$ \\
\hline 1 & \multirow{4}{*}{ Juni } & 10 & 3 & 2 \\
\hline 2 & & 9 & 2 & 2 \\
\hline 3 & & 9 & 3 & 2 \\
\hline 4 & & 8 & 2 & 2 \\
\hline 1 & \multirow{4}{*}{ Juli } & 8 & 3 & 2 \\
\hline 2 & & 7 & 2 & 2 \\
\hline 3 & & 7 & 2 & 4 \\
\hline 4 & & 9 & 2 & 3 \\
\hline 1 & \multirow{4}{*}{ Agustus } & 10 & 3 & 2 \\
\hline 2 & & 9 & 4 & 2 \\
\hline 3 & & 7 & 3 & 2 \\
\hline 4 & & 6 & 2 & 2 \\
\hline 1 & \multirow{4}{*}{ September } & 6 & 3 & 4 \\
\hline 2 & & 7 & 5 & 4 \\
\hline 3 & & 4 & 3 & 3 \\
\hline 4 & & 3 & 2 & 3 \\
\hline 1 & \multirow{4}{*}{ Oktober } & 4 & 2 & 2 \\
\hline 2 & & 6 & 4 & 3 \\
\hline 3 & & 4 & 2 & 3 \\
\hline 4 & & 4 & 4 & 3 \\
\hline
\end{tabular}

Dari hasil observasi tersebut persediaan paling sedikit terdapat pada minggu ke-4 bulan September yaitu sebanyak 3 botol, dan nilai persediaan terbanyak terdapat pada minggu ke-1 bulan Juni dan minggu ke-1 bulan Agustus yaitu sebanyak 10 botol. Untuk jumlah permintaan terendah yaitu sejumlah 2 botol dan permintaan tertinggi sebanyak 5 botol. Jumlah produksi tertinggi yaitu sebanyak 4 botol sedangkan jumlah produksi terendah sebanyak 2 botol.

Jika disajikan dalam tabel maka untuk nilai minimum dan maksimum persediaan, permintaan dan produksi hasilnya adalah seperti Tabel 2 di bawah ini:

Tabel 2. Nilai minimum dan maksimum.

\begin{tabular}{cccccc}
\hline \multicolumn{2}{c}{ Persediaan } & \multicolumn{2}{c}{ Permintaan } & \multicolumn{2}{c}{ Produksi } \\
\hline Tertinggi & Terendah & Tertinggi & Terendah & Tertinggi & Terendah \\
\hline 10 & 2 & 5 & 2 & 4 & 2 \\
\hline
\end{tabular}

Proses selanjutnya adalah nilai pada Tabel 2 digambarkan menggunakan metode fuzzy naik dan fuzzy turun untuk memperoleh persamaan dalam proses fuzzifikasi. Pada Gambar 4 menampilkan persediaan dinyatakan tinggi yang digambarkan dengan fuzzy naik seperti yang di bawah ini:

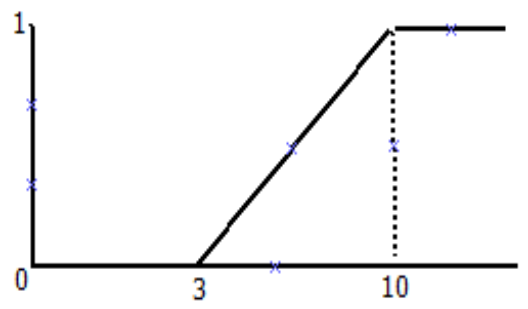

Gambar 4. Fuzzy persediaan tinggi.

Dari Gambar 4 di atas diperoleh persamaan sebagai berikut:

$$
\mu \text { psd tinggi }[x]=\left\{\begin{array}{c}
0 ; x \leq 3 \\
\frac{x-3}{7} ; 3<x<10 \\
1 ; x \geq 10
\end{array}\right.
$$



ini:

Persediaan dinyatakan rendah digambarkan dengan fuzzy turun seperti pada Gambar 5 di bawah

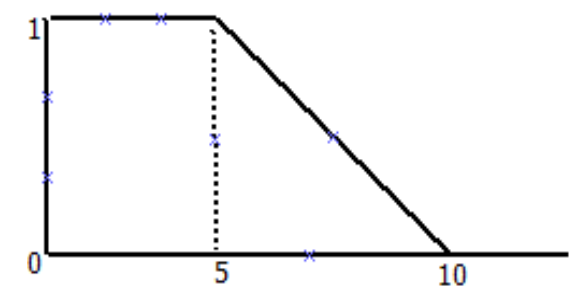

Gambar 5. Fuzzy persediaan rendah.

Dari Gambar 5 di atas diperoleh persamaan sebagai berikut:

$$
\mu \text { psd rendah }[x]=\left\{\begin{array}{c}
1 ; x \leq 3 \\
\frac{10-x}{7} ; 3<x<10 \\
1 ; x \geq 10
\end{array}\right.
$$

Permintaan dinyatakan tinggi digambarkan dengan fuzzy naik seperti pada Gambar 6 di bawah ini:

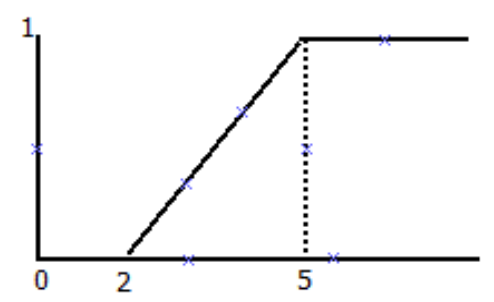

Gambar 6. Fuzzy permintaan tinggi.

Dari Gambar 6 di atas diperoleh persamaan sebagai berikut:

$$
\mu \text { pmt tinggi }[y]=\left\{\begin{array}{c}
0 ; y \leq 2 \\
\frac{y-2}{3} ; 2<y<5 \\
1 ; y \geq 5
\end{array}\right.
$$
ini:

Permintaan dinyatakan rendah digambarkan dengan fuzzy turun seperti pada Gambar 7 di bawah

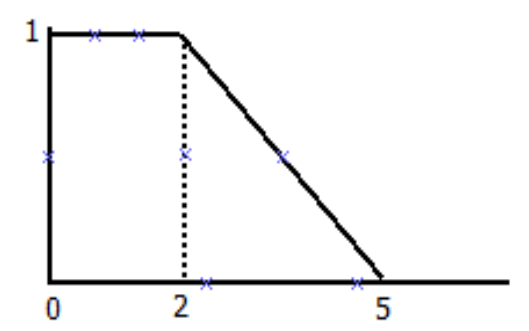

Gambar 7. Fuzzy permintaan rendah.

Dari Gambar 7 di atas diperoleh persamaan sebagai berikut:

$$
\mu \text { pmt rendah }[y]=\left\{\begin{array}{c}
1 ; y \leq 2 \\
\frac{5-y}{3} ; 2<y<5 \\
1 ; y \geq 5
\end{array}\right.
$$


Produksi dinyatakan tinggi digambarkan dengan fuzzy naik seperti pada Gambar 8 di bawah ini:

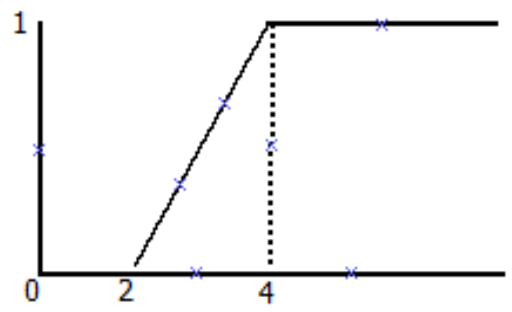

Gambar 8. Fuzzy produksi tinggi.

Dari Gambar 8 di atas diperoleh persamaan sebagai berikut:

$$
\mu \text { prd ting } i[z]=\left\{\begin{array}{c}
0 ; z \leq 2 \\
\frac{z-2}{2} ; 2<z<4 \\
1 ; z \geq 4
\end{array}\right.
$$

Produksi dinyatakan rendah digambarkan dengan fuzzy turun seperti pada Gambar 9 di bawah ini:

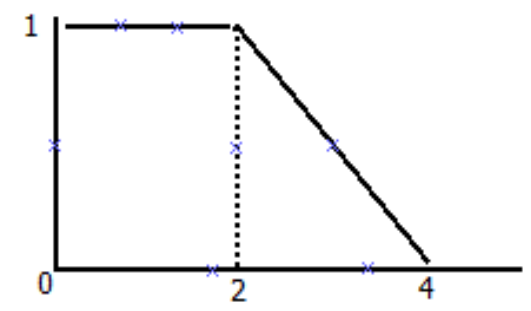

Gambar 9. Fuzzy Produksi Rendah.

Dari Gambar 9 di atas diperoleh persamaan sebagai berikut:

$$
\mu \text { prd rendah }[z]=\left\{\begin{array}{c}
1 ; z \leq 2 \\
\frac{4-z}{2} ; 2<z<4 \\
0 ; z \geq 4
\end{array}\right.
$$

\subsection{Pembahasan}

Terdapat 4 inferensi rule yang digunakan pada penelitian ini. Keempat inferensi rule tersebut dijabarkan sebagai berikut:

Tabel 3. Inferensi rule.

\begin{tabular}{ccc}
\hline No & Kondisi & Konklusi \\
\hline 1 & Jika Persediaan Tinggi dan Permintaan Tinggi & Produksi Tinggi \\
\hline 2 & Jika Persediaan Rendah dan Permintaan Tinggi & Produksi Tinggi \\
\hline 3 & Jika Persediaan Tinggi dan Permintaan Rendah & Produksi Rendah \\
\hline 4 & Jika Persediaan Rendah dan Permintaan Rendah & Produksi Rendah \\
\hline
\end{tabular}

Sebelum digunakan untuk penentuan jumlah produksi pada bulan selanjutnya, pengujian validitas penggunaan metode ini dilakukan dengan menghitung nilai produksi pada minggu ke-4 bulan September sampai dengan minggu ke-4 bulan Oktober. Data yang digunakan untuk menghitung produksi minggu ke4 bulan September adalah data persediaan dan permintaan pada minggu ke-3 bulan September. Data persediaan diketahui sejumlah 4 botol dan data permintaan sejumlah 3 botol. jumlah produksi dihitung menggunakan inferensi rule dan persamaan 1 hingga persamaan 4.

\section{Rule 1: Jika Persediaan Tinggi dan Permintaan Tinggi}

$\propto 1=\mu$ psd ting $i[x] \cap \mu$ pmt tinggi $[y]$

$=\min (\mu$ psd tinggi $[4], \mu$ pmt tinggi $[3])$ 
$=\min ([0.14],[0.33])$ (gunakan persamaan 1 dan 3 untuk memperoleh nilai tersebut)

$=0.14$

Rule 2: Jika Persediaan Rendah dan Permintaan Tinggi

$\propto 1=\mu$ psd rendah $[x] \cap \mu$ pmt ting $i[y]$

$=\min (\mu$ psd rendah[4], $\mu$ pmt tinggi [3] $)$

$=\min ([0.85],[0.33])$ (gunakan persamaan 2 dan 3 untuk memperoleh nilai tersebut)

$=0.33$

\section{Rule 3: Jika Persediaan Tinggi dan Permintaan Rendah}

$\propto 3=\mu$ psd ting $i[x] \cap \mu$ pmt rendah $[y]$

$=\min (\mu$ psd tinggi $[4], \mu$ pmt rendah $[3])$

$=\min ([0.14],[0.66])$ (gunakan persamaan 1 dan 4 untuk memperole nilai tersebut)

$=0.14$

Berdasarkan persamaan 6 untuk nilai produksi rendah adalah sebagai berikut:

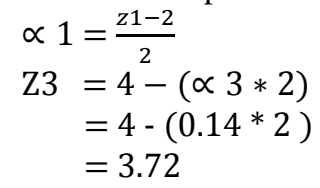

\section{Rule 4: Jika Persediaan Rendah dan Permintaan Rendah}

$\propto 4=\mu$ psd rendah $[x] \cap \mu$ pmt rendah $[y]$

$=\min (\mu$ psd rendah $[4], \mu$ pmt rendah $[3])$

$=\min ([0.85],[0.66])$ (gunakan persamaan 2 dan 4 untuk memperoleh nilai tersebut)

$=0.66$

Berdasarkan persamaan 6 untuk nilai produksi rendah adalah sebagai berikut:

$$
\begin{aligned}
\propto 4 & =\frac{4-z 4}{2} \\
\mathrm{Z} 4 & =4-(\propto 4 * 2) \\
& =4-(0.66 * 2) \\
& =2.68
\end{aligned}
$$

Proses selanjutnya adalah proses defuzzifikasi, pada penelitian ini menggunakan defuzzifikasi ratarata terpusat, yaitu dengan persamaan sebagai berikut:

$$
Z=\frac{\sum_{m=1}^{n} \propto_{m} \cdot z_{m}}{\sum_{m=1}^{n} \propto_{m}}
$$

Menggunakan persamaan 7 maka hasil dari defuzzifikasi dengan jumlah persediaan sebanyak 4 botol dan permintaan 3 botol adalah sebagai berikut:

$z=\frac{\propto 1 * Z 1+\propto 2 * Z 2+\propto 3 * Z 3+\propto 4 * Z 4}{\propto 1+\propto 2+\propto 3+\propto 4}$

$z=\frac{0.14 * 2.28+0.33 * 2.66+0.14 * 3.72+0.66 * 2.68}{0.14+0.33+0.14+0.66}$

$z=\frac{3.524}{1.28}$

$z=2.74$

Jadi hasil prediksi produksi pada minggu ke-4 bulan September adalah sebanyak 2,74 botol. Data perbandingan prediksi hasil produksi menggunakan Fuzzy Tsukamoto dan produksi yang telah dilakukan pada minggu ke-4 bulan September hingga minggu ke-4 Oktober ditampilkan pada Tabel 4 di bawah ini: 
Tabel 4. Tabel komparasi.

\begin{tabular}{|c|c|c|c|c|}
\hline $\begin{array}{c}\text { Waktu } \\
\text { Pelaksanaan }\end{array}$ & $\begin{array}{c}\text { Produksi Tanpa Fuzzy } \\
\text { Tsukamoto }\end{array}$ & $\begin{array}{c}\text { Prediksi Produksi Menggunakan } \\
\text { Fuzzy Tsukamoto } \\
\end{array}$ & Selisih & $\begin{array}{c}\text { Persentase } \\
\text { Akurasi }\end{array}$ \\
\hline Minggu ke 4 (Sept) & 3 & 2.74 & 0.26 & $91.33 \%$ \\
\hline Minggu ke $1(\mathrm{Okt})$ & 2 & 2 & 0 & $100.00 \%$ \\
\hline Minggu ke $2(\mathrm{Okt})$ & 3 & 2.49 & 0.51 & $83.00 \%$ \\
\hline Minggu ke $3(\mathrm{Okt})$ & 3 & 3.14 & -0.14 & $104.67 \%$ \\
\hline Minggu ke $4(\mathrm{Okt})$ & 3 & 2.49 & 0.51 & $83.00 \%$ \\
\hline
\end{tabular}

Berdasarkan pengujian tersebut, masih terdapat selisih antara produksi yang telah dilakukan dengan prediksi menggunakan Fuzzy Tsukamoto. Nilai persentase akurasi prediksi tidak kurang dari $83.00 \%$, dan nilai rata-rata akurasi persentase prediksi adalah $92.40 \%$. Melihat nilai persentase akurasi prediksi tersebut, peneliti merasa penggunaan metode Fuzzy Tsukamoto cukup akurat dalam prediksi produksi madu trigona di desa Kerandangan, Lombok Barat, Nusa Tenggara Barat. Peneliti memutuskan untuk melakukan prediksi produksi untuk minggu ke-1 bulan November 2020, hasilnya adalah 3.29 botol madu trigona yang mesti dihasilkan.

\section{Kesimpulan}

Berdasarkan analisa dan pengujian yang telah dilakukan pada penelitian ini, maka diperoleh kesimpulan bahwa penggunaan metode Fuzzy Tsukamoto dalam proses prediksi produksi madu trigona menghasilkan nilai rata-rata akurasi sebesar $92.40 \%$. Dan prediksi produksi pada minggu ke-1 bulan November menghasilkan nilai sebesar 3.29 botol.

Dalam penelitian ini tentunya masih jauh dari kata sempurna, diharapkan dalam penelitian selanjutnya jumlah data uji bisa lebih banyak, penggunaan metode lain ataupun kombinasi metode dalam proses prediksi dirasa dapat meningkatkan akurasi dalam proses prediksi.

\section{Daftar Pustaka}

[1] Balitbangtek, "Panduan Singkat Budidaya Breeding Lebah Trigona sp.," no. 7, pp. 1-19, 2018, [Online]. Available: http://balitbangtek-hhbk.org/2019/07/unggah/file-publikasi/panduan_trigonailovepdf-compressed_(1).pdf.

[2] R. YULIANA, E. SUTARININGSIH, H. B. SANTOSO, and S. D. RIENDRASARI, "Daya Antimikrobia Sarang Lebah Madu Trigona spp terhadap Mikrobia Patogen," Bioedukasi J. Pendidik. Biol., vol. 8, no. 1, p. 67, 2015, doi: 10.20961/bioedukasi-uns.v8i1.3546.

[3] C. Astria, H. Okprana, A. Wanto, D. Hartama, and H. S. Tambunan, "Implementasi Inferensi Fuzzy Tsukamoto pada Prediksi Penjualan Telur Ayam Eropa pada Bisnis Raffa Telur,” vol. 4, pp. 5861, 2020, doi: 10.30865/komik.v4i1.2587.

[4] U. Dian, N. Semarang, S. E. Smoothing, D. Exponential, and M. Peramalan, "Optimalisasi Jumlah Produksi Paving dan Batako Menggunakan Metode Fuzzy Inference System Tsukamoto dengan Peramalan," Yoga Adhi Wicaksono, Rindra Yusianto, Tota Talita, vol. 1, no. 5, pp. 1-9, 2014.

[5] M. . Riyadi Yudha Wiguna, Hanny Haryanto, S.Kom, "Sistem berbasis aturan menggunakan logika fuzzy tsukamoto untuk prediksi jumlah produksi roti pada cv. gendis bakery," Progr. Stud. Tek. Inform. Fak. Ilmu Komputer, Univ. Dian Nuswantoro, 2015.

[6] T. U. Azmi, H. Haryanto, and T. Sutojo, "Prediksi Jumlah Produksi Jenang di PT Menara Jenang Kudus Menggunakan Metode Logika Fuzzy Tsukamoto,” Sisfotenika, vol. 8, no. 1, p. 23, 2018, doi: $10.30700 /$ jst.v8i1.176.

[7] E. Sulistiani and S. Noris, "Penerapan FIS Metode Tsukamoto untuk Menentukan Kelayakan Pemberian Kredit," J. Inform. Univ. Pamulang, vol. 1, no. 1, pp. 22-27, 2016.

[8] N. S. Pinem and D. P. Utomo, "Implementasi Fuzzy Logic Dengan Infrensi Tsukamoto Untuk Prediksi Jumlah Kemasan Produksi (Studi Kasus: PT. Sinar Sosro Medan),” Pelita Inform. Inf. dan Inform., vol. 9, no. 1, pp. 56-60, 2020.

[9] R. N. C. Devi, S. T. Safitri, and F. M. Wibowo, "Penerapan Metode Fuzzy Logic Tsukamoto Dalam Penentu Alat Kontrasepsi," Pros. SENDI_U 2018, pp. 88-96, 2018.

[10] Y. Ferdiansyah and N. Hidayat, "Implementasi Metode Fuzzy - Tsukamoto Untuk Diagnosis Penyakit Pada Kelamin Laki Laki," J. Pengemb. Teknol. Inf. dan Ilmu Komput., vol. 2, no. 12, pp. 7516-7520, 2018. 